University of Nebraska - Lincoln

DigitalCommons@University of Nebraska - Lincoln

Faculty Papers and Publications in Animal

Science

Animal Science Department

1974

\title{
Influence of Nutritional Regime on Age at Puberty in Gilts
}

P. J. Cunningham

University of Nebraska-Lincoln

C. H. Nabor

Morgan County Community College

Dwane R. Zimmerman

University of Nebraska-Lincoln

E. R. Peo, Jr.

University of Nebraska-Lincoln

Follow this and additional works at: https://digitalcommons.unl.edu/animalscifacpub

Part of the Animal Sciences Commons

Cunningham, P. J.; Nabor, C. H.; Zimmerman, Dwane R.; and Peo, Jr., E. R., "Influence of Nutritional Regime on Age at Puberty in Gilts" (1974). Faculty Papers and Publications in Animal Science. 640.

https://digitalcommons.unl.edu/animalscifacpub/640

This Article is brought to you for free and open access by the Animal Science Department at DigitalCommons@University of Nebraska - Lincoln. It has been accepted for inclusion in Faculty Papers and Publications in Animal Science by an authorized administrator of DigitalCommons@University of Nebraska - Lincoln. 


\title{
INFLUENCE OF NUTRITIONAL REGIME ON AGE AT PUBERTY IN GILTS ${ }^{1}$
}

\author{
P. J. Cunningham, C. H. Naber ${ }^{2}$, Dwane R. Zimmerman ${ }^{3}$ and E. R. Peo, Jr.
}

University of Nebraska, Lincoln 68503

\begin{abstract}
Summary
Age at puberty was determined for 205 Gene Pool gilts; 68 fed a $10 \%$ protein diet (HLC) consisting of high-lysine corn, minerals and vitamins and 137 fed a $14 \%$ protein corn soybeam meal diet (CS). Gilts fed the CS diet reached puberty 18.7 days earlier than gilts fed the HLC diet. Use of postweaning daily gain as a covariable reduced the difference between diets to 9 days. The pooled within diet regression of age at puberty on post-weaning gain was -22.75 days per kilogram. The correlation between pubertal age and daily gain was significantly higher on the HLC diet $(-.30$ vs. $-.57 ; \mathrm{P}<.025)$ but the regressions for the two diets did not differ significantly $(-26.0$ vs. -18.4 days per kilogram).

Daughter-dam regressions were calculated for each diet separately. The coefficient for the $14 \%$ protein diet $(0.32)$ was significantly higher than for the $10 \%$ protein diet (-.14) indicating the existence of a genotype-environment interaction.
\end{abstract}

\section{Introduction}

Plant protein sources may eventually become unavailable or limiting for use in swine diets. This situation may arise due to increased demand of plant protein for human consumption which may limit availability or increase the cost to a point where use in swine diets is impractical. Swine populations will then have to perform efficiently on lower protein diets if the industry is to remain competitive.

\footnotetext{
${ }^{1}$ Published with the approval of the Director as Paper No. 3490 Journal Series, Nebraska Agr. Exp. Sta. Research reported was conducted under Project 13-29.

${ }^{2}$ Present address: Morgan County Community College, Fort Morgan, Colorado.

${ }^{3}$ Department of Animal Science.
}

Efficient performance includes not oniy growth and feed utilization, but reproductive performance as well.

Early puberty is important in the gilt because of the positive relationship between sexual age (number of estrous periods expressed prior to breeding) and ovulation rate (Robertson et al., 1951; Self, Grummer and Casida, 1955; Warnick et al., 1951).

These data represent the puberty data from the base population of a selection experiment designed to determine the effectiveness of selection for lean growth (index including daily gain and probe backfat thickness) under two nutritional regimes. One diet contains no supplemental plant protein.

\section{Materials and Methods}

Two-hundred-five September-farrowed Gene Pool (a synthetic involving 14 breeds and closed for five generations) gilts were randomly assigned within litter to two diets prior to weaning. After all gilts were weaned at approximately 42 days of age, they were allotted on the basis of age to drylot pens of 18 to 20 gilts and started on their respective diet. The two diets (fed ad libitum) were a $10 \%$ protein diet (HLC) and a 14\% protein diet (CS). The HLC diet consisted of high-lysine corn, minerals and vitamins with a calculated ME value of $3,256 \mathrm{kcal} / \mathrm{kg}$ while the CS diet was a standard corn-soybean meal diet with a calculated ME value of $3,199 \mathrm{kcal} / \mathrm{kg}$ (table 1). Sixty-eight gilts received the HLC diet and 137 the CS diet. Larger numbers were assigned to the CS diet because gilts randomly designated for both a control and select line were fed this diet.

Gilts were weighed weekly beginning when the oldest gilts were 135 days of age. Gilts were removed from test and backfat probes taken at approximately 79.4 kilograms. The experimental period was terminated for all remaining $6 \overline{3}$

JOURNAL OF ANIMAL SCIENCE, Vol. 39, No. 1, 1974 
TABLE 1. COMPOSITION OF THE DIETS

\begin{tabular}{|c|c|c|}
\hline Ingredient & $\begin{array}{l}14 \% \\
\text { Corn-soy basal } \\
(\mathrm{CS})^{\mathrm{a}}\end{array}$ & $\begin{array}{l}10 \% \\
\text { High lysine } \\
(\mathrm{HLC})^{a}\end{array}$ \\
\hline $\begin{array}{l}\text { Corn, dent yellow } \\
\text { gr } 2 \text { US mn } 54 \text { wt., } \\
\text { (4) }\end{array}$ & 83.65 & - \\
\hline $\begin{array}{l}\text { Corn, dent yellow } \\
\text { (opaque-2) gr } 2 \text { US } \\
\text { mn } 52 \text { wt., (4)c }\end{array}$ & - & 95.95 \\
\hline $\begin{array}{l}\text { Soybean, seed wo } \\
\text { hulls, solv-extd } \\
\text { grnd, } \mathrm{mx} 3, \mathrm{fbr},(5)\end{array}$ & 12.45 & 一 \\
\hline Limestone, grnd, mn & & \\
\hline $33 \mathrm{Ca},(6)$ & 0.45 & 0.25 \\
\hline $\begin{array}{l}\text { Calcium phosphate, } \\
\text { dibasic, comm, (6) }\end{array}$ & 1.90 & 2.25 \\
\hline Salt (1) & 0.50 & 0.50 \\
\hline Trace minerals $d$ & 0.05 & 0.05 \\
\hline $\begin{array}{l}\text { Vitamin-anti- } \\
\text { botic mix }\end{array}$ & 1.00 & 1.00 \\
\hline
\end{tabular}

${ }^{a}$ Calculated ME value for the CS diet was 3199 $\mathrm{kcal} / \mathrm{kg}$; for the HLC diet, $3,256 \mathrm{kcal} / \mathrm{kg}$.

bCorn, dent yellow analyzed $9.5 \%$ crude protein; $0.31 \%$ lysine on an as fed basis.

corn, dent yellow (opaque-2) analyzed $10.5 \%$ crude protein; $0.51 \%$ lysine on an as fed basis.

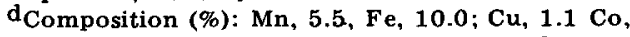
$0.1 ; 1,0.15 ; \mathrm{Zn}, 20$. Calcium Carbonate Co., Quincy, Illinois.

e Contributed the following vitamins and antibiotics per $\mathrm{kg}$ of diet: Vit $A, 2640 \mathrm{IU}$; Vit $\mathrm{D}_{3}, 396 \mathrm{IU}$ riboflavin, $1.76 \mathrm{mg}$; pantothenic acid, $6.60 \mathrm{mg}$; niacin, $17.6 \mathrm{mg}$; choline chloride, $110 \mathrm{mg}$; Vit $B_{12}, 11 \mathrm{mcg}$ and chlortetracycline-sulfamethazine-penicillin combination in a 1:1:0.5 ratio, $275 \mathrm{mg}$ vitamins, courtesy Dawes Laboratories Inc., Chicago; antibiotics courtesy American Cyanamid Co., Princeton, New Jersey.

gilts after 150 days on the experimental diets. After being removed from test, all gilts were interval fed (ad libitum for $2 \mathrm{hr}$. every $48 \mathrm{hr}$.) the CS diet.

Probe backfat thickness measurements were adjusted to $90.7 \mathrm{~kg}$ using an adjustment factor of $0.0224 \mathrm{~cm} / \mathrm{kilogram}$. An index value, consisting of postweaning daily gain and adjusted probe backfat, was computed for each gilt $[\mathrm{I}=100+28.66$ (gain) -3.94 (probe) $]$. Parameters used in the index construction have been defined previously (Cunninghan et al, 1973). The index value is the selection criteria to be used in selection of replacements in future generations. Probe backfats were not taken and indexes not calculated for one gilt on the CS diet and four gilts on the HLC diet because they did not weigh at least $68 \mathrm{~kg}$ at the conclusion of the test.
Observations for estrus were made once daily (am) with intact boars beginning at approximately 125 days of age. Estrus checks were continued until each gilt expressed two estrous periods. Seven gilts had not cycled by approximately 240 days of age and were slaughtered. Four of the seven had anatomically normal reproductive tracts and were included in the data as having attained puberty on the day of slaughter. Three of the four were on the HLC diet. Three other gilts had abnormal reproductive tracts and were not included in the data.

Analysis of variance, regression and correlation procedures (Steel and Torrie, 1960) were used to evaluate the effect of diet on age at puberty and its relationship to other traits.

\section{Results and Discussion}

Means and standard deviations of the traits measured are presented in table 2. Standard deviations for daily gain, probe backfat and age at puberty are larger for gilts fed the HLC diet indicating the existence of greater variability among gilts on the low protein diet. Diet differences $(\mathrm{P}<.01)$ existed for gain, probe backfat and index. Gilts fed the HLC diet grew more slowly and were fatter, indicating a slower rate of lean growth (Cunningham et al., 1973).

Age at Puberty. The mean age at puberty for the 205 Gene Pool gilts was 166.1 days (range from 133 to 239 days). This is an expression of first estrus at a younger age than has been reported by most investigators (Robertson et

TABLE 2. PERFORMANCE OF GILTS FED $14 \%$ CORN-SOY AND 10\% HIGH LYSINE DIETS

\begin{tabular}{|c|c|c|c|c|}
\hline \multirow[b]{2}{*}{ Trait } & \multicolumn{2}{|c|}{$\begin{array}{c}14 \% \\
\text { Corn-soy basal } \\
\text { (CS) }\end{array}$} & \multicolumn{2}{|c|}{$\begin{array}{c}10 \% \\
\text { High lysine } \\
\text { (HLC) }\end{array}$} \\
\hline & $\overline{\text { Mean }}$ & SD & $\overline{\text { Mean }}$ & SD \\
\hline 42 Day wt, & 12.6 & 3.2 & 13.0 & 3.0 \\
\hline $\begin{array}{l}\text { Daily gain, } \\
\text { kga } \\
\text { Backfat }\end{array}$ & 0.63 & 0.07 & 0.54 & 0.11 \\
\hline $\begin{array}{l}\text { probe, } \\
\text { cma }^{\mathrm{a}}\end{array}$ & 3.53 & 0.45 & 4.00 & 0.58 \\
\hline Index ${ }^{a}$ & 104.19 & 2.67 & 100.28 & 2.4 \\
\hline $\begin{array}{l}\text { Age at pu- } \\
\text { berty } \\
\text { daya }^{\mathrm{a}}\end{array}$ & 159.8 & 21.10 & 178.7 & 25.30 \\
\hline
\end{tabular}

a Diet differences significant $(P<.01)$. 
al., 1951; Burger, 1952; Self et al., 1955; Haines, Warnick and Wallace, 1959; Gossett and Sorensen, 1959; Zimmerman et al., 1960; Sorensen, Thomas and Gossett, 1961; O'Bannon et al., 1966), but is typical of this population (Reutzel and Sumption, 1968; Zimmerman, Carlson and Nippert, 1969). The combination of genetic material from 14 breeds and the possibility that some heterosis may still exist in this population may be responsible for the early onset of puberty. Foote et al. (1956) and Zimmerman et al. (1960) have reported a marked heterotic influence on age at puberty in the pig.

Gilts fed the $14 \%$ protein CS diet reached puberty an average of 18.9 days earlier (159.8 vs. 178.7 days) than gilts fed the $10 \%$ protein HLC diet $(\mathrm{P}<.005)$. This is a relatively large difference and may indicate the importance of total dietary protein and amino acid balance for pubertal development.

Protein and/or amino acid requirements for pubertal development clearly exceeded that supplied by the $10 \%$ HLC diet. Also, daily intake of protein and essential amino acids was further reduced in the gilts fed the HLC diet compared to those fed the $14 \%$ protein CS diet as evident by the reduced feed intake (1.77 vs. $2.06 \mathrm{~kg} /$ day) of littermate gilts fed for carcass evaluation (Cunningham et al., 1973).

The negative pubertal response to low protein is in contrast to the results reported by Robertson et al. (1951). They found that 15\% and $11.25 \%$ protein diets provided before and after $57 \mathrm{~kg}$, respectively, resulted in earlier puberty than $20 \%$ and $15 \%$ protein diets. However, the protein intakes supplied by their diets were not as low as the protein intake on the $10 \%$ protein diet of this study. This was especially true prior to 57 kilograms.

The extent to which the retarded growth rate of the gilts on the HLC diet (.54 vs. .63 $\mathrm{kg} /$ day for those on the CS diet) may have influenced the difference in age at puberty was examined by including daily gain as a covariable in the analysis of variance. The diet difference was decreased from 19 to 9 days (163.2 vs. 172.0 days), but the difference remained significant $(\mathrm{P}<.01)$. The HLC diet apparently influenced sexual development to even a greater extent than it did somatic development. The pooled within diet regression of age at puberty on daily gain was -22.75 days per kilogram. Other workers have also observed a negative relationship between gain or weight for age and age at puberty in swine (Robertson et al., 1951; Warnick et al., 1951; Squiers, Dickerson and
Mayer, 1952; Self et al., 1955; Foote et al., 1956; Haines et al., 1959; Zimmerman et al., 1960).

The selection index value calculated for each gilt was an attempt to quantify rate of lean growth utilizing genetic, phenotypic and economic parameters. As a covariable, the index value accounted for a significant $(P<$ .005 ) amount of the variation in age at puberty. The adjusted diet difference of eight days $(\mathrm{P}<$ .05 ) was similar to the difference following adjustment for gain only. The pooled within treatment regression coefficient was -2.05 days per index unit. These results indicate that the faster the rate of lean growth, the younger the age at puberty. The use of both daily gain and probe backfat as covariables was slightly more efficient than the use of the index value.

Correlations. Correlations between age at puberty and other measures of performance indicate the relationship between pubertal development and development of other body tissues. The influence of diet on these relationships may be particularly informative. Simple correlations between age at puberty and the other traits measured are presented in table 3 for each diet separately.

All traits measured were negatively related to age at puberty for both diets. Except for correlations between age and probe backfat, all correlations were significantly different from zero $(\mathrm{P}<.05)$. These correlations indicate a tendency for the faster growing gilts to reach puberty at a younger age. This tendency was expressed as early as weaning time. Variation in weight at 42 days of age would account for almost as much variation in age at puberty as daily gain following weaning. However, none of the traits measured would account for more than $10 \%$ of the variation in age at puberty except for daily gain on the HLC diet. Factors

TABLE 3. SIMPLE CORRELATIONS WITH AGE AT PUBERTY

\begin{tabular}{lll}
\hline \hline Trait & $\begin{array}{c}14 \% \\
\text { Corn-soy basal } \\
\text { (CS) }\end{array}$ & $\begin{array}{c}10 \% \\
\text { High lysine } \\
\text { (HLC) }\end{array}$ \\
\hline 42 day wta & $-.25^{*}$ & $-.32^{*}$ \\
Daily gainac & $-.30^{*}$ & $-.57^{*}$ \\
Probe backfatb & -.02 & -.11 \\
Index b & $-.21^{*}$ & $-.32^{*}$ \\
\hline
\end{tabular}

* Significantly different from zero $(P<.05)$.

a Number of observations; $137 \mathrm{CS}$ and 68 HLC.

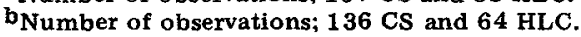

cSignificant difference between diets $(P<.025)$. 
other than growth rate are also influencing age at puberty. Squiers et al. (1952) reported a correlation between daily gain and puberty age of -.27 . Also, correlations of -.27 and -.29 between puberty age and 154 day weight have been reported by Self et al. (1955) and Robertson et al. (1951), respectively. These results agree closely with the value of -.30 obtained for the CS diet in this study. Reutzel and Sumption (1968) found correlations of -.10 for age and 42 day weight and 0.08 between age and probe backfat.

Correlations were consistently larger for the HLC diet than the CS diet. However, only the correlations between age at puberty and daily gain were significantly different $(P<.025)$ for the two diets. The association was almost twice as high ( -.57 vs. -.30$)$. for the HLC diet.

No significant differences were found between the regression coefficients for the two diets $(-26.0$ vs. -18.4 days $/ \mathrm{kg})$ indicating that the change in pubertal age per unit change in gain is similar for the two diets. However, growth rate was a more accurate predictor of age at puberty for the $10 \%$ protein HLC diet.

Genetic Considerations. These data have indicated that a $10 \%$ protein diet increased the age at puberty in gilts. A point of interest would be whether this low protein diet affected all genotypes equally or whether some genotypes were affected more than others (genotype-diet interaction). Daughter-dam regressions were calculated separately for each diet (table 4). A total of 63 dams was involved with 60 having daughters on the CS diet and 55 on the HLC diet. All dams were raised on a standard $14 \%$ protein corn soybean meal diet. Each dam, rather than each daughter, was weighted equally in regression analysis.

The regression of $0.32(\mathrm{P}<.05)$ obtained for the CS diet results in an estimated heritability of 0.64 . Therefore, selection for age at puberty should be effective under this

TABLE 4. DAUGHTER-DAM REGRESSIONS FOR AGE AT PUBERTY

\begin{tabular}{|c|c|c|c|c|}
\hline Diet & $\begin{array}{l}\text { Number } \\
\text { pairs }\end{array}$ & $\mathbf{b}^{\mathbf{a}}$ & SE & $\mathbf{r}$ \\
\hline $\begin{array}{l}14 \% \text { Corn-soy } \\
\text { (CS) } \\
10 \% \text { High lysine }\end{array}$ & 60 & $0.32 *$ & 0.15 & $0.27 *$ \\
\hline (HLC) & 55 & -.14 & 0.18 & -.11 \\
\hline
\end{tabular}

*Significantly different from zero $(P<.05)$.

asignificant diet difference $(P<.05)$. nutritional regime. Reutzel and Sumption (1968) reported a heritability estimate for age at puberty of 0.49 also based on daughter-dam regression.

The daughter-dam regression obtained for the HLC diet, though not significantly different from zero, was negative $(-.14)$. Dickerson (1969) has shown the expectation for a daughter-dam regression in detail. Several covariances exist in the expectation which could contribute to a negative estimate. In addition, since the dams and daughters were fed different diets, it seems possible that the additive variance may actually be a covariance (a covariance attributed to average direct effects of genes expressed in two environments).

The regression coefficients for the two diets were significantly different $(P<.05)$. This result plus the negative sign of the estimate obtained for the HLC diet indicate that genotypes were affected differently by the two diets. A genotype-diet interaction may exist such that genes responsible for variation in age at puberty under the CS regime are at best independent and possibly opposite in their effect on age at puberty under the HLC regime. Subsequent generations of the experiment will provide data with both dams and daughters evaluated under the HLC regime. These data can be used to assess the effectiveness of selection for age at puberty in the HLC environment.

\section{Literature Cited}

Burger, J. F. 1952. Sex physiology of pigs. Onderstepoort. J. Vet. Res. Suppl. 2, p. 218.

Cunningham, P. J., T. E. Socha, E. R. Peo, Jr - and R. W. Mandigo. 1973. Gain, feed conversion and carcass traits of swine fed under two nutritional regimes. J. Anim. Sci. 37:75.

Dickerson, G.E. 1969. Techniques for research in quantitative animal genetics. Techniques and Procedures in Animal Science Research, p. 36-79. Amer. Soc. Anim. Sci.

Foote, W. C., D. P. Waldorf, A. B. Chapman, H. L. Self, R. H. Grummer and L. E. Casida. 1956. Age at puberty of gilts produced by different systems of mating. J. Anim. Sci. 15:959.

Gossett, J. W. and A. M. Sorensen, Jr. 1959. The effects of two levels of energy and seasons on reproductive phenomena of gilts. J. Anim. Sci. 18:40.

Haines, C. E., A. C. Warnick and H. D. Wallace. 1959. The effects of two levels of energy intake on reproductive phenomena in Duroc Jersey gilts. J. Anim. Sci. 18:347.

O'Bannon, R. H., H. D. Wallace, A. C. Warnick and G. E. Combs. 1966. Influence of energy intake on reproductive performance of gilts. J. Anim. Sci.
$25: 706$. 
Reutzel, L. F. and L. J. Sumption. 1968. Genetic and phenotypic relationships involving age at puberty and growth rate of gilts. J. Anim. Sci. 27:27.

Robertson, G. L., L. E. Casida, R. H. Grummer and A. B. Chapman. 1951. Some feeding and management factors affecting age at puberty and related phenomena in Chester White and Poland China gilts. J. Anim. Sci. 10:841.

Self, H. L., R. H. Grummer and L. E. Casida. 1955 The effect of various sequences of full and limited feeding on the reproductive phenomena in Chester White and Poland China gilts. J. Anim. Sci. 14:573

Steel, R. G. and J. H. Torrie. 1960. Principles and Procedures of Statistics. McGraw-Hill Book Co., New York.

Sorensen, A. M. Jr., W. B. Thomas and J. W. Gossett. 1961. A further study of the influence of level of energy and season on reproductive performance of gilts. J. Anim. Sci. 20:347.

Squiers, C. D., C. E. Dickerson and D. T. Mayer. 1952. Influence of inbreeding, age and growth rate of sows on sexual maturity, rate of ovulation, fertilization and embryonic survival. Mo. Agr. Exp. Sta. Res. Bull. 494.

Warnick, A. C., E. L. Wiggins, L. E. Casida, R. H. Grummer and A. B. Chapman. 1951. Variation in puberty phenomena in inbred gilts. J. Anim. Sci. 10:479.

Zimmerman, D. R., Roy Carlson and Larry Nippert. 1969. Age at puberty in gilts as affected by daily heat checks with a boar. J. Anim. Sci. 29:203. (Abstr.).

Zimmerman, D. R., H. G. Spies, E. M. Rigor, H. L. Self and L. E. Casida. 1960. Effects of restricted feeding, crossbreeding and season of birth on age of puberty in swine. J. Anim. Sci. 19:687. 